\title{
Antioxidant and Antifungal Activity of Endophytic Fungi Associated with Agarwood Trees ${ }^{1}$
}

\author{
Asep Hidayat $\mathbb{B}^{2, \dagger} \cdot$ Maman Turjaman ${ }^{2} \cdot$ Sarah Asih Faulina ${ }^{2} \cdot$ Fadel Ridwan $^{3}$ • \\ Aryanto $^{2} \cdot$ Najmulah $^{2} \cdot$ Tun Tedja Irawadi ${ }^{3} \cdot$ Apri Heri Iswanto ${ }^{4}$
}

\begin{abstract}
Several species of Aquilaria and Gyrinops are native to Indonesia and well known as agarwood-producing trees with a high economic value. Their bioactive compounds have a wide spectrum of uses, such as in medicine and cosmetics. These genera have undergone extensive search for novel bioactive compounds. The purpose of this study was to isolate, identify, and characterize the endophytic fungi community associated with Aquilaria malaccensis, A. microcarpa, Gyrinops versteegii, and A. crassna trees and investigate their bioactive properties as antioxidant agents and antagonists. A total of 50 fungi were successfully isolated from different tissues of the four species of agarwood-producing trees. Two isolates exhibited strong antioxidant activity, namely, Apodus oryzae (R2MC3A, IC $5060.92 \mathrm{mg} / \mathrm{mL}$ ) and Diaporthe sp. (P1DS1[C], IC $5076.65 \mathrm{mg} / \mathrm{mL}$ ). Two isolates, Pestalotiopsis theae (P3BS3[B]) and Curvularia sp. (P2CD3A), showed $>75 \%$ antifungal activity against pathogenic Fusarium solani. The results revealed that endophytic fungi associated with the studied agarwood-producing trees had potential antioxidant and antifungal activities for further applications in biotechnology.
\end{abstract}

Keywords: Aquilaria, Gyrinops, endophytic fungi, antioxidant, antagonists

\section{INTRODUCTION}

Thymelaeceae is the major plant family producing agarwood, also called Gaharu in Indonesian. Agarwood have been used as one of the essential ingredients in fragrance, aromatherapy, pharmaceutical and herbal medicines for centuries. It also hold social, cultural, and economic values in local communities (Beek and Philips, 1999; Barden et al., 2000; Donovan and Puri,
2004). Indonesian agarwood has been known worldwide and retained long historical story. It was first recorded as the main commodity bartered between the empires of China and the kingdoms of Indonesia since the Silk Road era (Turjaman et al., 2016). Wider spectrums of agarwood uses have been known for sedative in oriental medicine, antimicrobial, antitumor and antioxidant activity (Takemoto et al., 2008; Wetwitayaklung et al., 2009; Chen et al., 2011). Agarwood is the resinous

\footnotetext{
${ }^{1}$ Date Received March 16, 2019, Date Accepted July 15, 2019

${ }^{2}$ Forest Microbiology Laboratory, Forest research and Development Centre, Research, Development and Innovation Agency, Ministry of Environmental and Forestry. Jl. Gunung Batu No. 5., Bogor 16001, West Java, Indonesia

${ }^{3}$ Department of Chemistry, Faculty of Mathematics and Natural Sciences, Bogor Agricultural University. Jl. Tanjung Kampus IPB, Dramaga, Bogor 16680, West Java, Indonesia

${ }^{4}$ Department of Forest Product, Faculty of Forestry, Universitas Sumatera Utara, Padang Bulan, Medan 20155, Indonesia

$\dagger$ Corresponding author: Asep Hidayat (e-mail: ashephidayat12@gmail.com, ORCID: 0000-0003-3755-072X)
} 
Asep Hidayat - Maman Turjaman • Sarah Asih Faulina • Fadel Ridwan •

Aryanto $\cdot$ Najmulah $\cdot$ Tun Tedja Irawadi $\cdot$ Apri Heri Iswanto

and fragrant heartwood that may not be formed in normal wood tissue but formed in wounded trees. Among them, Aquilaria and Gyrinops are the most common agarwood-producing genus in Indonesia (Gong and Guo, 2009). Different parts of various plant have been known to have various benefit (Jung et al., 2017. Ham and Kim, 2018; Li et al., 2018), healthy wood of Aquilaria and Gyrinops have been acknowledge to contain bioactive compound; leaves demonstrated inhibition activity against polymorphonuclear neutrophils (PMNs) respiratory burst stimulated by PMA (Qi et al., 2009), anti-diabetic, anti-HIV, anti-cancer, immuno-modulatory anti-inflammatory and laxative effects (Yoshimi et al., 2001); while fresh steam exhibited cytotoxicity against SGC-7901 and SMMC7721 cell lines (Wang et al., 2010).

Parallel with the huge loss of agarwood producingtree in the wild, the losses of endophytic fungi associated with the trees automatically determine the loss of Indonesia biodiversity as well. Agarwood-producing tress are host for many endophytic fungi which produce similar or even higher amount of bioactive substrates compare to their host plant (Stierle et al., 1993; Strobel et al., 1996; Li et al., 1998). Previous studies have recorded that 1) Fusarium spp. isolated from leaves, steam and root of $A$. sinensis showed the most potent antimicrobial activity, 2) several endophytes fungi (Gong and Guo, 2009) isolated form A. crassna showed capability to produce indole-3-acetic acid (IAA) and siderophores (Nimnoi et al., 2010), 3) F. verticillioides SHTr3 and Colletotrichum truncatum SHTrHc7 isolated from A. crassna showed comparable scavenging abilities on DPPH-free radicals (Chi et al., 2016), 4) Xylaria mali, Lasiodiplodia theobromae and Phaeoacremonium rubrigenum isolated form $A$. sinensis exhibited cytotoxicity against 293-T, 293-T, and SKVO3 cells lines (Cui et al., 2011), and 5) fungus AL-2 strain isolated from $A$. malaccensis had antibacterial activities against gram positive and negative bacteria as well as general toxicity based on brine shrimp lethality (Shoeb et al., 2010). A. sinensis have been used as traditional Chinese medicinal, a tropical evergreen tree distributed in Hainan, Guangdong, Guangxi, Yunnan and Taiwan (Chen et al., 2016); A. crassna used also as traditional medical plant and widely distributed in Indochina and Thailand (Turjaman and Hidayat, 2017); and so that for A. malaccensis which is the most popular species for its agarwood production and distributed from different countries, Bangladesh, Bhutan, Cambodia, India, Indonesia, Iran, Lao PRD, Malaysia, Myanmar, Philippines, Singapore, Thailand, Vietnam and Papua New Guinea (Oldfield et al., 1998; Premalatha and Kalra, 2013).

The genus Aquilaria has 27 species spread worldwide, which 6 are found in Indonesia (Soehartono and Newton, 2000; Saikia and Khan, 2013). The genus Gyrinops is distributed in at least 12 countries, and 7 species were found naturally in Indonesia (Barden et al., 2000). Several studies have been previously conducted to those species, particularly on exploration and investigation of their phytochemical constituents and their respective endophytic fungi bioactivities. There was vast variations of endophytic fungal communities related to living conditions, host plant species, as well as host tissue types (Lamit et al., 2014); indicating that further investigations are important. For this reason, this study aimed to isolate the understudied endophytic fungi associated with three Indonesia-native species of agarwood (A. malaccensis and A. microcarpa, $G$. versteegii) and one exotic species (A. crassna), as well as their antioxidant and antifungal activities.

\section{MATERIALS and METHODS}

\subsection{Chemicals}

Alcohol, $\mathrm{NaClO} 4 \%$, Dextrose, $\mathrm{KOH} \mathrm{10 \% ,} \mathrm{HCl}$, Glycerol 20\%, acetic acid anhydrite, magnesium (Mg), 
$\mathrm{H}_{2} \mathrm{SO}_{4}$, Folin-Ciocalteu (FC), ethyl acetate and methanol were purchased from Merck chemical (Germany). 1,1-diphenyl-2-picrylhydrazyl (DPPH) was purchased from Sigma-Aldrich chemical (USA) and other chemicals were provided by Himedia chemicals (India).

\subsection{Samples and cultures medium for isolation}

Different parts of plant materials (healthy segment; bark, leaves, shoot and root) from Aquilaria and Gyrinops trees originated from West Java and Bangka were collected (diameter breast high $/ \mathrm{dbh}>15 \mathrm{~cm}$, either grown naturally or planted). The potato dextrose agar (PDA), which consist of potato extract $20 \%$, dextrose $2 \%$, and agar $2 \%$ was used for isolation. Pure fungal strains were sub-cultured and maintained on PDA prior to use. Malt Yeast Glucose Agar (MYGA, containing yeast extract $0.4 \%$, malt extract $1 \%$, sucrose $0.4 \%$, and agar 2\%), and Malt Yeast Glucose Pepton Agar (MYGPA, which consist of yeast extract $0.3 \%$, malt extract $0.3 \%$, peptone $0.5 \%$, sucrose $1.05 \%$, and agar $2 \%$ ) were also used to obtain optimum fungal growth (Atlas, 2004).

\subsection{Endophytic fungal isolation}

Fungal strains were isolated from bark, leaves, shoot, and root of A. malaccensis, A. microcarpa, A. crasna and $G$. verstigii trees. The tree parts were collected at least from three different trees. In order to minimize the growth of epiphytic fungi during internal tissue sampling, tree parts were surface-sterilized by washing, followed by soaking in alcohol $70 \%$ for $2 \mathrm{~min}$, and lastly in sodium hypochlorite for $2 \mathrm{~min}$ ( $4 \% \mathrm{Cl}$ active). The outer tissues were removed, and the inner tissues of 0.5 x $0.5 \mathrm{~cm}$ size were carefully dissected and placed in PDA media plates. Chloramphenicol (100 mg/L) was added to media to suppress bacterial growth. The plates were then incubated at room temperature for up to 14 days, during which the development of different colonies was periodically observed and verified. Each colonies of different fungi appeared from tissue fragment were cut out by dissecting microscope and purified on PDA plates. All pure cultures obtained were used for further investigation.

To select the most suitable medium for each isolate, the pure cultures were tested on PDA, MYGA and MYGPA media. A disk (5 mm, diameter) of actively growing fungal colony on agar media was obtained with a cork-borer and was sub-cultured into petri dish containing PDA, MYGA and MYGPA media. The plate was incubated for $7 \mathrm{~d}$, and the fungal growth was observed daily. All the experiments were conducted in triplicate.

\subsection{Screening of endophytic fungi against $F$. solani in dual culture}

F. solani was obtained from Laboratory of Forest Microbiology (INTROF-CC 00509, Forest Research and Development Centre, Bogor, Indonesia) All pure strains of fungal endophytes were screened against $F$. solani in dual cultures on PDA. An agar disk (5 mm diameter) of endophytic and $F$. solani was co-inoculated $4 \mathrm{~cm}$ apart on PDA in petri dish. The plates were incubated at room temperature up to 7 days. All experiments were carried out in triplicates. Growth inhibition percentage was determined by the following formula (Dennis and Webster, 1971).

Percentage of inhibition $=[(\mathrm{J} 1-\mathrm{J} 2) / \mathrm{J} 1] \times 100 \%$

Where $\mathrm{J} 1$ is radial covered by pathogen toward petri dish wall (outward), and $\mathrm{J} 2$ is radial covered by pathogen ( $F$. solani) toward endophytic fungi.

\subsection{Screening of fungal endophytes for antioxidant activity}

\subsubsection{Preparation of fungal extraction}

Each of endophytic fungal isolates was grown in 250 
Asep Hidayat - Maman Turjaman • Sarah Asih Faulina • Fadel Ridwan •

Aryanto $\cdot$ Najmulah $\cdot$ Tun Tedja Irawadi $\cdot$ Apri Heri Iswanto

$\mathrm{mL}$ Erlenmeyer flasks containing $50 \mathrm{ml}$ of selected liquid medium (previously described) and incubated for 14 days in stationary condition. After incubation, mycelia biomass was harvested by filtering through Whatman No. 1 filter paper. The filter papers containing mycelia mat were oven dried until constant weight was reached, then extracted by ethyl acetate. The filtrate was also extracted by ethyl acetate using funnel separation. Each organic phase was mixed, and the solvent was then removed under reduced pressure using rotary vacuum evaporator to obtain a concentrate. The yield of ethyl acetate soluble was determined by calculation with dried weight of fungal mycelium (\%, $\mathrm{w} / \mathrm{w})$ and volume of culture liquid medium $(\%, \mathrm{w} / \mathrm{v})$.

\subsubsection{Antioxidant assay}

Antioxidant activity of each extract was determined according to published methods with slight modifications (Kamonwannasit et al., 2013; Marson Ascêncio et al., 2014; Sadeghi et al., 2015). In a series of test tubes, extract was diluted with ethyl acetate to obtain in the range of concentration into which $0.25 \mathrm{~mL}$ of a DPPH (1 M) and added methanol to obtain $2.5 \mathrm{~mL}$ of final reaction volume. After $30 \mathrm{~min}$ incubation at room temperature, the absorbance was monitored at $517 \mathrm{~nm}$. The ethyl acetatesolution without extracts was selected as control. All experiments were conducted in triplicated test. The inhibitory activity was calculated from $\left[\left(A_{0}-A_{1}\right) / A_{0}\right] \times 100$, where $A_{0}$ is the absorbance of the control, and $A_{1}$ is the absorbance of the extract or standard. The antioxidant activity was expressed as $\mathrm{IC}_{50}$, in which the amount of sample necessary to reduce the initial DPPH concentration by half.

\subsubsection{Phytochemical assay}

Phytochemical assay was carried out according to Tapwal et al. (2016) with slight modification, including detection of some important constituents (phenolic, flavonoid, tannin, steroid, terpenoid, and alkaloid). All ethyl acetate soluble obtained from extraction (pre- viously described) with concentration of $1000 \mu \mathrm{g} / \mathrm{L}$ was subjected for phytochemical assay. In general, phenolic and tannin were reacted by ferric chloride test, flavonoid was determined by addition of magnesium and hydrochloric acid, steroid was monitored by addition of acetate anhydrate and sulfuric acid, terpenoid was determined by addition of sulfuric acid, and alkaloid was monitored by using Mayer's and Wagner's reagents.

\subsection{Identification of fungi}

Fungal identification was done with molecular methods, focusing on fungi with antioxidant and antifungal properties. DNA was obtained by extraction of mycelia cultured in $7 \mathrm{~d}$ grown on potato dextrose broth (PBD) using DNA Wizard Kit (Promega, USA) according to the published method (Kumar and Shukla, 2005). The internal transcribed spacer ITS region (Jellison and Jasalavich, 2000) was amplified by polymerase chain reaction (PCR) using ITS1 (5'-CTTGGTCATTTAG AGGAAGTAA-3') and ITS4-B (5'-CAGGAGACTT GTACAGGTCCAG-3’). The PCR was performed in $20 \mu \mathrm{l}$ of solution containing $10 \mathrm{ng}$ of genomic DNA, 5 pmol each of the forward and reverse primers, and $10 \mu$ of Go Taq ${ }^{\circledR}$ Hot Start Colourless Master Mix (Promega, Wisconsin USA) according to the manufacturer's instructions. Prior to sequencing, the PCR products were purified using rAPid Alkaline Phosphatase (Roche, Germany) and exo-nuclease I (New England Biolabs, Massachusetts, USA). The purified PCR products were Sanger sequenced (First Base Sequencing Service, Singapore). Homology searches were conducted by using the BLASTn program in the National Center for Biotechnology Information (NCBI) GenBank database (http://www.ncbi.nlm.nih.gov/).

\subsection{Statistical analysis}

All results were presented as the mean \pm the standard deviation. When necessary, results were also analysed 
using SPSS (version 15) for Windows.

\section{RESULTS and DISCUSSION}

\subsection{Endophytic fungi isolation}

Total of 50 endophytic fungal isolate was successfully purified from 232 different part of fresh and healthy plant material belonging to A. malaccensis, A. microcarpa, A. crassna and G. Versteegii collected from West Java and Bangka Belitung Provinces. There were 24, 16, 7 and 3 pure endophytic fungal isolates from bark, leaves, shoot, and root, respectively. All fungal isolates were able to grow in all three media, with most of them showed highest colony growth in PDA (80\%), MYGA (14\%) and MYGPA (6\%) (data not shown here). Hence, PDA and its equivalent liquid medium, potato dextrose broth (PDB), were selected for further investigation on antioxidant and antifungal properties. Endophytic microorganisms, mostly fungi in general, are localized internally in their host plants and become an important issue in the past few decades (Faeth, 2002; Staniek et al., 2008). Endophytic fungi thrive asymptomatically in the tissues of plants including stems, leaves, barks and/or roots. They may help clarify the role and biological change in stressful environments. Pure endophytic fungal isolates from $G$. versteegii were most abundant (21 strains) among other host plant species in this study; A. crassna (14 strain), A. microcarpa (7 strains) and A. malaccensis (3 strains). The isolation of endophytic fungi by traditional method in this study have revealed a new finding, particularly originated from G. verstegii and A. microcarpa, which has never been conducted before and could serve as a reference for the next studies. Whereas the diversity of endophytic fungi and their various potential bioactive metabolites from A. crassna and A malaccensis in this study has contributed to wider knowledge of the potential use of endophytic fungi for agarwood-producing trees as has been previously reports (Nimnoi et al., 2010; Shoeb et al., 2010; Chi et al., 2016).

\subsection{Antioxidant activity}

In this study, 50 endophytic fungal isolates were evaluated for antioxidant activity. The results revealed that among 50 isolates, six had ability to reduce the absorbance of DDPH free radical with the range was 36\% - 82\% (Table 1); P1C1S3 (39.87 \pm 2.61 ), P2CD3B (36.25 \pm 0.01$), \mathrm{P} 1 \mathrm{DS} 1[\mathrm{C}](65.25 \pm 0.73), \mathrm{P} 3 \mathrm{DS} 1[\mathrm{~A}]$ (46.5 \pm 2.33$)$, P1B1C (40.67 \pm 0.73$)$, and R2MC3A (82.08 \pm 5.99). Further analysis (Table 1$)$ indicated that the ethyl acetate extracts from two isolates, R2MC3A and P1DS1[C] had IC $_{50}$ of $60.92 \mu \mathrm{g} / \mathrm{mL}$ and $76.65 \mu \mathrm{g} / \mathrm{mL}$, fall into the range of strong category (50-100 $\mu \mathrm{g} / \mathrm{mL}$ ). Whereas other isolates those had $\mathrm{IC}_{50}$ fall under the range of medium category (100-150 $\mu \mathrm{g} / \mathrm{mL})$. The ethyl acetate extract of R2MC3A resulted in higher yield, $0.06 \%(\mathrm{w} / \mathrm{v})$ or $11.97 \% \mathrm{w} / \mathrm{w}$ of dried mycelia, than of P1DS1[C] (Table 2). These results indicated that the highest potential antioxidant was generated from endophytes isolated from fresh leaves (P1DS1[C]) and roots (R2MC3A) of G. verstegii and A. microcarpa trees.

Molecular identification clearly identified Diaporthe sp. (P1DS1[C]) and Apodus oryzae. (R2MC3A), both have $\mathrm{IC}_{50}$ less than $80 \mu \mathrm{g} / \mathrm{mL}$ (Table 3). Interestingly, Diaporthe sp. has been known as a genus of plant pathogenic, saprobic and endophytic fungi (Gomes et al., 2013); while Apodus oryzae (R2MC3A) has been known as aminor endophytic and rhizospheric fungi associated with several plants (Cai et al., 2006; Zhou et al., 2015). In contrast, Apodus oryzae isolate (R2MC3A) showed greater scavenging activity (IC 50 $60.92 \mu \mathrm{g} / \mathrm{mL}$ ) than Diaporthe sp. (P1DS1[C]) isolate. This study is the first report to discover that Apodus oryzae (R2MC3A) and Diaporthe sp. played as endophytic fungi which resided in the leaves tissue of 
Asep Hidayat $\cdot$ Maman Turjaman - Sarah Asih Faulina • Fadel Ridwan •

Aryanto $\cdot$ Najmulah $\cdot$ Tun Tedja Irawadi $\cdot$ Apri Heri Iswanto

Table 1. Antioxidant and antifungal activity of thirteen potential endophytic fungi

\begin{tabular}{|c|c|c|c|c|c|c|c|}
\hline \multirow[b]{2}{*}{ Explants } & \multirow[b]{2}{*}{ Host Plants } & & \multirow[b]{2}{*}{ Isolates } & \multicolumn{3}{|c|}{ Antioxidants } & \multirow{2}{*}{$\begin{array}{c}\text { Antifungal } \\
(\%)\end{array}$} \\
\hline & & & & $\begin{array}{c}\text { Inhibitory } \\
\text { Activity (\%)* }\end{array}$ & $\begin{array}{c}\mathrm{IC}_{50} \\
(\mu \mathrm{g} / \mathrm{mL})\end{array}$ & Categories** & \\
\hline \multirow{6}{*}{ Bark } & \multirow{2}{*}{ G. versteegii } & 1 & P3C2S3 [B] & $18.37 \pm 7.058$ & $>200$ & 1 & $71.42 \pm 0.82$ \\
\hline & & 2 & $\mathrm{P} 1 \mathrm{C} 1 \mathrm{~S} 3$ [B] & $39.87 \pm 2.611$ & 125.41 & 3 & $49.39 \pm 5.57$ \\
\hline & \multirow{4}{*}{ A. crassna } & 1 & $\mathrm{P} 1 \mathrm{CD} 2 \mathrm{~B}$ & $11.59 \pm 1.753$ & $>200$ & 1 & $72.00 \pm 0.00$ \\
\hline & & 2 & P2CD3A & $7.42 \pm 1.244$ & $>200$ & 1 & $77.00 \pm 4.24$ \\
\hline & & 3 & P2CD3B & $36.25 \pm 0.004$ & 137.93 & 3 & $64.00 \pm 5.66$ \\
\hline & & 4 & P2CK1B & $10.50 \pm 0.121$ & $>200$ & 1 & $73.67 \pm 13.67$ \\
\hline \multirow{4}{*}{ Leaves } & \multirow{2}{*}{ G. versteegii } & 1 & P1DS1[C] & $65.24 \pm 0.728$ & 76.65 & 4 & $59.21 \pm 11.57$ \\
\hline & & 2 & P3DS1[A] & $46.50 \pm 2.333$ & 107.53 & 3 & $61.11 \pm 7.85$ \\
\hline & A. crassna & 1 & P1D2A & $6.44 \pm 0.155$ & $>200$ & 1 & $72.54 \pm 0.76$ \\
\hline & A. microcarpa & 1 & LMC3D11 & $6.58 \pm 0.280$ & $>200$ & 1 & $70.00 \pm 2.31$ \\
\hline \multirow{2}{*}{ shoot } & G. versteegii & 1 & P3BS3 [B] & $14.44 \pm 3.611$ & $>200$ & 1 & $78.46 \pm 7.84$ \\
\hline & A. crassna & 1 & P1B1C & $40.60 \pm 0.728$ & 123.15 & 3 & $51.65 \pm 7.77$ \\
\hline Root & A. microcarpa & 1 & R2MC3A & $82.08 \pm 5.990$ & 60.92 & 4 & $9.17 \pm 1.44$ \\
\hline
\end{tabular}

Note: * concentration of fungal crude extract $(100 \mathrm{mg} / \mathrm{L})$;

** 1 = very weak, 2 = weak, $3=$ medium, $4=$ strong, 5 = very strong

G. verstegii and the roots of A. microcarpa. Previous studies reported that only Fusarium, Colletotrichum, Xylaria, Lasiodiplodia, Phaeoacremonium, have been isolated from A. sinensis, A. crassna and A malaccensis (Gong and Guo, 2009; Nimnoi et al., 2010; Shoeb et al., 2010; Cui et al., 2011; Chi et al., 2016). Diaporthe sp. has been previously described as endophyte and produce bioactive secondary metabolites which are antioxidant potential. However, antioxidant activity between isolates varies greatly. For example, Diaporthe sp isolated from Costus spiralis have shown antioxidant activity ( $\mathrm{IC}_{50}$ ) between 500-1750 $\mu \mathrm{g} / \mathrm{mL}$ (Marson Ascêncio et al., 2014), whereas IC $_{50}$ of $76.65 \mu \mathrm{g} / \mathrm{mL}$ were obtained from Diaporthe sp (P1DS1[C]) isolated from leaves tissue of G. verstegii. Diaporthe sp. was reported to produce bioactiverelated to phenolic compounds, such as benzene acetaldehyde, benzyl benzoate, salicylaldehyde, benzoin and benzyl cinnamate (Tanapichatsakul et al., 2018).
Other interesting finding is the antioxidant capacity of Apodus sp. Apodus sp. was previously reported to be found in Hedyotis diffusa and Pseudotsuga menziesii (Zhou et al., 2015; Daniels, 2017). However, the information on its antioxidant activity was not yet investigated. The antioxidant activity of Apodus oryzae (R2MC3A), among other isolates in this study, was the highest $(60.92 \mu \mathrm{g} / \mathrm{mL})$ and confirmed to contain a phenolic compound (Table 2); achieving the total phenolic content (TPC) $96.10 \mathrm{mg}$ gallic acid equivalent per g sample (data not shown here). The detection of TPC content clearly supported other findings on antioxidant capacity closely related with TPC (Sadeghi et al., 2015; Jeong et al., 2017; Hidayat et al., 2018; Kim et al., 2018). Although, the specific phenolic compound was not yet identified, the phenolic content itself is important due to its unique structure for redox property which acts as high reducing agents, hydrogen donators, and singlet oxygen quenchers which may lead 
Table 2. Biomass, yield and phytochemical analyisis of crude extract etyl acetate soluble of 13 isolates endophytic fungi after fermentation at 14 days

\begin{tabular}{|c|c|c|c|c|c|c|c|c|c|c|c|c|c|}
\hline \multirow{3}{*}{ Explants } & \multirow{3}{*}{\multicolumn{2}{|c|}{$\begin{array}{l}\text { Host } \\
\text { Plants }\end{array}$}} & \multirow{3}{*}{\multicolumn{2}{|c|}{ Isolates }} & \multirow{3}{*}{$\begin{array}{c}\text { Mycelium } \\
\text { Weight } \\
(\mathrm{mg} / \mathrm{L})\end{array}$} & \multicolumn{2}{|c|}{$\begin{array}{l}\text { Yield of Ethyl } \\
\text { Acetate Soluble } \\
\text { Extracts }\end{array}$} & \multicolumn{6}{|c|}{ Phytochemical Properties } \\
\hline & & & & & & \multirow{2}{*}{$\begin{array}{c}\% \\
(w / v)^{*}\end{array}$} & \multirow{2}{*}{$\begin{array}{c}\% \\
(\mathrm{w} / \mathrm{w})^{* *}\end{array}$} & \multicolumn{2}{|c|}{ Alkaloid } & \multirow{2}{*}{ Flavonoid* } & \multirow{2}{*}{ Fenol* } & \multirow{2}{*}{ Terpenoid } & \multirow{2}{*}{ Steroid } \\
\hline & & & & & & & & Mayer & Wagner & & & & \\
\hline \multirow{6}{*}{ Bark } & \multirow{2}{*}{ G. } & \multirow{2}{*}{ versteegii } & 1 & P3C2S3 [B] & 6,354 & 0.02 & 3.02 & - & - & + & + & + & - \\
\hline & & & 2 & P1C1S3 [B] & 59,813 & 0,07 & 1.14 & - & - & + & + & - & + \\
\hline & \multirow{4}{*}{ A. $c$} & \multirow{4}{*}{ crassna } & 1 & P1CD2B & 9,957 & 0,05 & 4.86 & - & - & - & + & + & - \\
\hline & & & 2 & P2CD3A & 9,083 & 0,04 & 4.36 & - & - & + & - & + & + \\
\hline & & & 3 & P2CD3B & 5,850 & 0,03 & 4.99 & - & - & - & + & + & - \\
\hline & & & 4 & P2CK1B & 5,570 & 0,03 & 6.13 & - & - & + & + & + & - \\
\hline \multirow{4}{*}{ Leaves } & \multirow{2}{*}{\multicolumn{2}{|c|}{ G. versteegii }} & 1 & P1DS1[C] & 7,461 & 0.03 & 4.66 & - & - & + & + & + & - \\
\hline & & & 2 & P3DS1[A] & 6,082 & 0.06 & 10.06 & - & - & + & + & + & - \\
\hline & A. & crassna & 1 & P1D2A & 4,315 & 0,06 & 13.52 & - & - & + & - & + & - \\
\hline & A. & microcarpa & 1 & LMC3D11 & 10,395 & 0.02 & 2.20 & - & - & - & + & - & + \\
\hline \multirow{2}{*}{ Shoot } & G. & versteegii & 1 & P3BS3 [B] & 6,936 & 0.03 & 3.81 & - & - & + & - & + & - \\
\hline & A. & crassna & 1 & P1B1C & 3,069 & 0,04 & 12.49 & - & - & - & + & + & - \\
\hline Root & A. & microcarpa & 1 & R2MC3A & 4,691 & 0.06 & 11.97 & - & - & - & + & - & + \\
\hline
\end{tabular}

Noted: * calculated with volume of liquid medium, $* *$ calculated with mycelium weight, $+=$ indicates presence,

- = indicates absence

to antioxidant activity (Khoddami et al., 2013; Kim et al., 2017).

\subsection{Antifungal against $F$. solani activity}

Antifungal activity tested by means of dual culture/confrontation against $F$. solani. Fusarium was recorded as a significant plant pathogen and an inducer of agarwood formulation (Sitepu et al., 2011; Turjaman et al., 2016). This pathogenic fungi was commonly used to induce agarwood formation and one of the most effective agent for agarwood formation in Indonesia (Turjaman et al., 2016). The effectiveness of agarwood formation was affected by many factors such as host tree, type of fungal pathogen, and environment (Santoso, 2013), as well as the presence of endophytic fungi inside the host tree (Nimnoi et al., 2011; Zhang et al., 2014). In this study, 50 endophytic fungi showed variation in the capability to inhibit the growth of $F$. solani (9-78\%). Seven isolates inhibited the growth of $F$. solani over than 70\%, (Table 1), those were P2CK1B (73\%), P1D2A (72\%), P1CD2B (72\%), P2CD3A (77\%), P3BS3[B] (78\%), P3C2S3[B] (71\%), and LMC3D11 (70\%). Most above-ground tree isolates had strong antifungal activity against $F$. solani, while R2MC3A, which was originated from the root, had a weak antifungal activity. It revealed that R2MC3A was not compatible to work against $F$. solani, which produced symptoms on the infected root (Sitepu et al., 2011; Turjaman et al., 2016). More detailed observation on tissue origin and host plant species revealed that the strongest inhibitions (> 75\%) were originated from shoot (P3BS3[B]) and bark (P2CD3A) of G. verstegii and A. crassna trees. According to molecular identification (Table 3), isolate P3BS3[B] and P2CD3A were clearly identified as $P$. theae and Curvularia sp. 
Asep Hidayat $\cdot$ Maman Turjaman $\cdot$ Sarah Asih Faulina $\cdot$ Fadel Ridwan •

Aryanto $\cdot$ Najmulah $\cdot$ Tun Tedja Irawadi $\cdot$ Apri Heri Iswanto

Table 3. Identification of 13 potential endophytic fungi based on internal transcribed spacer (ITS) using BLAST analysis

\begin{tabular}{|c|c|c|c|c|c|c|c|}
\hline Explants & $\begin{array}{c}\text { Host } \\
\text { plants }\end{array}$ & & Isolates & $\begin{array}{l}\text { Similarity } \\
\text { (\%) }\end{array}$ & Species & $\begin{array}{l}\text { Accession } \\
\text { number }\end{array}$ & Division, class, family \\
\hline \multirow{6}{*}{ Bark } & \multirow[b]{2}{*}{ G. versteegii } & 1 & P3C2S3 [B] & - & - & - & - \\
\hline & & 2 & P1C1S3 [B] & 99 & $\begin{array}{l}\text { Daldinia } \\
\text { eschscholtzii }\end{array}$ & КТ936498 & $\begin{array}{l}\text { Ascomycota, Ascomycetes, } \\
\text { Xylariaceae }\end{array}$ \\
\hline & \multirow{4}{*}{ A. crassna } & 1 & P1CD2B & - & - & - & - \\
\hline & & 2 & P2CD3A & 100 & Curvularia sp. & КР377591 & $\begin{array}{l}\text { Ascomycota, Euascomycetes, } \\
\text { Pleosporaceae }\end{array}$ \\
\hline & & 3 & P2CD3B & 100 & $\begin{array}{l}\text { Aspergillus } \\
\text { flavus }\end{array}$ & KY962966 & $\begin{array}{l}\text { Ascomycota, Eurotiomycetes, } \\
\text { Trichocomaceae }\end{array}$ \\
\hline & & 4 & P2CK1B & 100 & Aspergillus sp. & KY587316 & $\begin{array}{l}\text { Ascomycota, Eurotiomycetes, } \\
\text { Trichocomaceae }\end{array}$ \\
\hline \multirow{4}{*}{ Leaves } & \multirow{2}{*}{ G. versteegii } & 1 & P1DS1[C] & 100 & Diaporthe sp & EF423549 & $\begin{array}{l}\text { Ascomycota, Sordariomycetes, } \\
\text { Diaporthaceae }\end{array}$ \\
\hline & & 2 & P3DS1[A] & 100 & $\begin{array}{l}\text { Colletotrichum } \\
\text { magnum }\end{array}$ & KC815123 & $\begin{array}{l}\text { Ascomycota, Sordariomycetes, } \\
\text { Glomerellaceae }\end{array}$ \\
\hline & A. crassna & 1 & P1D2A & 99 & $\begin{array}{l}\text { Phyllosticta } \\
\text { capitalensis }\end{array}$ & KP900294 & $\begin{array}{l}\text { Ascomycota, Dothideomycetes, } \\
\text { Botryosphaeriaceae }\end{array}$ \\
\hline & A. microcarpa & 1 & LMC3D11 & 99 & Diaporthe sp & EF423549 & $\begin{array}{l}\text { Ascomycota, Sordariomycetes, } \\
\text { Diaporthaceae }\end{array}$ \\
\hline \multirow[t]{2}{*}{ Shoot } & G. versteegii & 1 & P3BS3 [B] & 100 & $\begin{array}{l}\text { Pestalotiopsis } \\
\text { theae }\end{array}$ & EU833970 & $\begin{array}{l}\text { Ascomycota, Sordariomycetes, } \\
\text { Pestalotiopsidaceae }\end{array}$ \\
\hline & A. crassna & 1 & P1B1C & - & - & - & - \\
\hline Root & A. microcarpa & 1 & R2MC3A & 100 & Apodus oryzae & KU059868 & $\begin{array}{l}\text { Ascomycota, Sordariomycetes, } \\
\text { Sporacadaceae }\end{array}$ \\
\hline
\end{tabular}

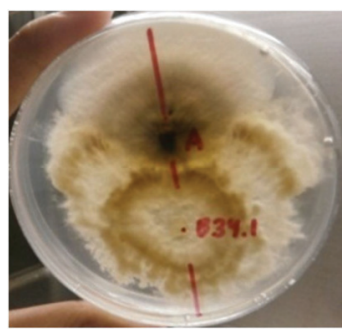

(a)

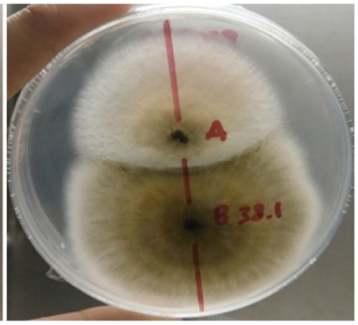

(b)
Fig. 1. Dual culture assay between potential endophytic against the pathogen of $F$. solani after 6 days incubation. A. P. theae P3BS3[B], B. Curvularia sp. (P2CD3A).

The interaction between two potential endophytic and pathogenic fungi showed in Fig. 1. It was categorized as type E interaction (Wheeler and Hocking, 1993), where the mycelia of $P$. theae and Curvularia sp. continued to grow, covered and reduced pathogen's colony. In the Curvularia sp - F.solani interaction, green black color appeared at the border of the two colonies. Yellow brown was appeared circling the mycelium of $P$. theae interacted with F.solani. This phenomenon showed that both colonies competed to access nutrients, secreted certain enzymes, and produced bioactive compounds to cease the opponent's growth by changing of fungal cell membrane (Hamzah et al., 2018; Kim et al., 2016). As an indicator of bioactive compound production, the phytochemical assay from ethyl acetate extract of fungal culture of $P$. theae and Curvularia 
sp. assayed and showed a positive result to flavonoid, terpenoid and/or steroid constituent (Table 2). Compounds constituents from endophytes of Genus Pestalotiopsis and Curvularia have been previously reported (Tan and Zou, 2001; Kaul et al., 2012; Mondol et al., 2017; Alurappa and Chowdappa, 2018; Chutulo and Chalannavar, 2018; Deshmukh et al., 2018). Pestalotiopsis sp. with the huge diversity of endophytic fungi has appeared as potential source of bioactive natural compounds. They have been reported to produce various compounds such as alkaloids, terpenoids, flavonoids, and phenols, which has been reported to have antimicrobial, antifungal, antiviral antineoplastic, and antioxidant activities (Deshmukh et al., 2017). The terpenoid compounds isolated from the endophyte Pestalotiopsis sp. was the most abundant compound among other constituents, which are moderate to high antifungal property, such as 10-Deacetylbaccatin III, Pestalofone C, Pestalofone E, (3R,4R,6R,7S)-7hydroxyl-3,7-dimethyl-oxabicyclo[3.3.1]nonan-2-one, and (3R,4R)-3-(7-methylcyclohexenyl)-propanoic acid (Deshmukh et al. 2017, 2018). Curvularia sp. isolated from Rauwolfia tetraphylla L. was reported to contain alkaloid and terpenoid, and had antifungal activity (Alurappa and Chowdappa, 2018). Pyrenolide A produced from Curvularia sp., strain M12, was isolated from Murraya koenigii and showed strong activity against Phytophthora capsici (Mondol et al., 2017). Studies on agarwood production in genera Aquilaria and Gyrinops reported that only $7-10 \%$ of tree contains agarwood, which sesquiterpenes and 2-(2-phenylethyl)4H-chromen-4-one was the major chemical constituent (Naef, 2011; Chen et al., 2012). Although terpenoids have been found in the host plant (agarwood) as well as on the potential endophytic fungi in this study, the relationship between them are still unclear; whether it is mutualistic, symbiotic, antagonistic, or slightly pathogenic.

\section{CONCLUSION}

Fitty endophytic fungi were successfully isolated from different parts of A. malaccensis, A. microcarpa, A. crassna and G. verstegii trees grown in West Java and Bangka Belitung Provinces, Indonesia. Among them, Diaporthe sp. (P1DS1[C]) and A. oryzae. (R2MC3A) originated from fresh leave G. verstegii and root of A.microcarpa produced phenolic chemical groups which have antioxidant activities $\left(\mathrm{IC}_{50}\right)$ less than $80 \mu \mathrm{g} / \mathrm{mL}$. Two other isolates, P. theae (P3BS3[B]) and Curvularia sp (P2CD3A) originated from fresh shoot of G. verstegii and bark of A. crassna showed antifungal activity against the phytopathogenic fungi F. solani, potentially by producing terpenoid chemical groups constituent. New finding of the occurrence of endophytic fungi (Diaporthe sp., A. oryzae, P. theae, Curvularia sp.) may be used as the bioresources for antioxidant and also as antifungal agents for wider biotechnology applications in the future.

\section{ACKNOWLEDGMENT}

This work was partly supported by Ministry of Environmental and Forestry, Republic of Indonesia, FY 2016. We thanks to our colleagues for helping and supporting to our research work and critical comments in writing of manuscript. Asep Hidayat and Maman Turjaman conceived and designed the experiments, collected samples, performed the experiments, analysed and interpreted the data, contributed reagents, materials, analysis tools, wrote and edited the manuscripts. Sarah Asih Faulina helped with fungal identification, wrote and edited the manuscripts. Fadel Ridwan, Aryanto, Najmulah collected samples and performed experiments. Tun Tedja Irwanti wrote and edited the manuscripts. All authors reviewed and approval final manuscripts. 
Asep Hidayat - Maman Turjaman • Sarah Asih Faulina • Fadel Ridwan •

Aryanto $\cdot$ Najmulah $\cdot$ Tun Tedja Irawadi - Apri Heri Iswanto

\section{REFERENCES}

Alurappa, R., Chowdappa, S. 2018. Antimicrobial activity and phytochemical analysis of endophytic fungal extracts isolated from ethno-pharmaceutical plant Rauwolfia tetraphylla L. Ramesha. Journal of Pure and AppliedMicrobiology 12(1): 317-332.

Atlas, R.M. 2004. Handbook of microbiological media. CRC Press, Florida, USA.

Barden, A., Anak, N.A., Mulliken, T., Song, M. 2000. Heart of the matter: agarwood use and trade and CITES implementation for Aquilaria malaccensis. Cambridge : TRAFFIC International.

Beek, H.H.v., Philips, D. 1999. Agarwood: trade and CITES implementation in Southeast Asia.

Cai, L., Jeewon, R., Hyde, K.D. 2006. Phylogenetic investigations of Sordariaceae based on multiple gene sequences and morphology. Mycological Research 110(2): 137-150.

Chen, G., Liu, C., Sun, W. 2016. Pollination and seed dispersal of Aquilaria sinensis (Lour.) Gilg (Thymelaeaceae): An economic plant species with extremely small populations in China. Plant Diversity 38(5): 227-232.

Chen, H., Yang, Y., Xue, J., Wei, J., Zhang, Z., Chen, H. 2011. Comparison of compositions and antimicrobial activities of essential oils from chemically stimulated agarwood, wild agarwood and healthy Aquilaria sinensis (Lour.) Gilg trees. Molecules 16(6): 4884-4896.

Chen, H.Q., Wei, J.H., Yang, J.S., Zhang, Z., Yang, Y., Gao, Z.H., Sui, C., Gong, B. 2012. Chemical constituents of agarwood originating from the endemic genus Aquilaria plants. Chemical \& Biodiversity 9(2): 236-250.

Chi, H.K., Cuong, L.H., Hang, T.T.N., Luyen, N.D., Ha, T.T.H., Huong, L.M. 2016. Biological characterization of fungal endophytes isolated from agarwood tree Aquilaria crassna Pierre Ex
Lecomte. Vietnam Journal of Biotechnology 14(1): 149-156.

Chutulo, E.C., Chalannavar, R.K. 2018. Endophytic mycoflora and their bioactive compounds from Azadirachta Indica : A comprehensive review. Journal of Fungi 4(2): 1-12.

Cui, J., Guo, S., Xiao, P. 2011. Antitumor and antimicrobial activities of endophytic fungi from medicinal parts of Aquilaria sinensis. Journal of Zhejiang University Science B 12(5): 385-392.

Daniels, H.A. 2017. Phylogenetic identification of pathogenic and endophytic fungal populations in west Coast Douglas-fir (Pseudotsuga menziesii) Foliage. Oregon State University.

Dennis, C., Webster, J. 1971. Antagonistic properties of species-groups of Trichoderma: III. Hyphal interaction. Transaction of the British Mycological Society 57(3): 363-369.

Deshmukh, S., Gupta, M., Prakash, V., Saxena, S. 2018. Endophytic Fungi: A source of potential antifungal compounds. Journal of Fungi 4(3): 77.

Deshmukh, S.K., Prakash, V., Ranjan, N. 2017. Recent advances in the discovery of bioactive metabolites from Pestalotiopsis. Phytochemistry Reviews 16(5): 883-920.

Donovan, D.G., Puri, R.K. 2004. Learning from traditional knowledge of non-timber forest products: Penan Benalui and the Autecology of Aquilaria in Indonesian Borneo. Ecology and Society 9(3): 3.

Faeth, S.H. 2002. Are endophytic fungi defensive plant mutualists? Oikos 98: 25-36.

Gomes, R.R., Glienke, C., Videira, S.I.R., Lombard, L., Groenewald, J.Z., Crous, P.W. 2013. Diaporthe: A genus of endophytic, saprobic and plant pathogenic fungi. Persoonia-Molecular Phylogeny and Evolution of Fungi 31: 1-41.

Gong, L.J., Guo, S.X. 2009. Endophytic fungi from Dracaena cambodiana and Aquilaria sinensis and their antimicrobial activity. African Journal of 
Biotechnology 8(5): 731-736.

Ham, Y., Kim, T-J. 2018. Plant extracts inhibiting biofilm formation by Streptococcus mutans without antibiotic Activity. Journal of the Korean Wood Science and Technology 46(6): 692-702.

Hamzah, T.N.T., Lee, S.Y., Hidayat, A., Terhem, R., Faridah-hanum, I., Mohamed, R. 2018 Diversity and characterization of endophytic fungi isolated from the tropical mangrove species, Rhizophora mucronata, and identification of potential antagonists against the soil-borne fungus, Fusarium solani. Frontiers in Microbiology 9: 1707.

Hidayat, A., Iswanto, A.P., Susilowati, A., Rachmat, H.H. 2018. Radical scavenging activity of kemenyan resin produced by an Indonesian native plant, Styrax sumatrana. Journal of the Korean Wood Science and Technology 46(4): 346-354.

Jellison, J., Jasalavich, C. 2000.A review of selected methods for the detection of degradative fungi. International Biodeterioration \& Biodegradation 46(3): 241-244.

Jeong, M-J., Yang, J., Choi, W-S., Kim, J-W., Kim, S-J., Park, M-J. 2017. Chemical compositions and antioxidant activities of essential oil extracted from Neolitsea aciculata(Blume) Koidz leaves. Journal of the Korean Wood Science and Technology 45(1): 96-106.

Jung, J-Y., Yang, J-K., Lee, W-H. 2017. Antioxidant and safety test of natural extract of Quercus mongolica. Journal of the Korean Wood Science and Technology 45(1): 116-125.

Kamonwannasit, S., Nantapong, N., Kumkrai, P., Luecha, P., Kupittayanan, S., Chudapongse, N. 2013. Antibacterial activity of Aquilaria crassna leaf extract against Staphylococcus epidermidis by disruption of cell wall. Annals of Clinical Microbiology and Antimicrobials 12(20): 1-7.

Kaul, S., Gupta, S., Ahmed, M., Dhar, M.K. 2012. Endophytic fungi from medicinal plants: A treasure hunt for bioactive metabolites. Phytochemistry Reviewa 11(4): 487-505.

Kim, J-W., Um, M., Lee, J-W. 2018. Antioxidant activities of hot water extracts from different parts of Rugosa rose (Rosa rugosa Thunb.). Journal of the Korean Wood Science and Technology 46(1): 38-47.

Kim, S-H., Lee, S-Y., Cho, S-M., Hong, C-Y., Park, S-Y., Park, M-J., Choi, I-G. 2017. Antioxidant activities of Cryptomeria japonica leaves extracts by extraction Methods. Journal of the Korean Wood Science and Technology 45(5): 495-510.

Kim, S-H., Lee, S-Y., Cho, S-M., Hong, C-Y., Park, M-J., Choi, I-G, 2016. Evaluation on anti-fungal activity and synergy effects of essential oil and their constituents from Abies holophylla. Journal of the Korean Wood Science and Technology 44(1): 113-123.

Khoddami, A., Wilkes, M.A., Roberts, T.H. 2013. Techniques for analysis of plant phenolic compounds. Molecules 18(2): 2328-2375.

Kumar, M., Shukla, P.K. 2005. Use of PCR targeting of internal transcribed spacer regions and singlestranded conformation polymorphism analysis of sequence variation in different regions of rRNA genes in fungi for rapid diagnosis of mycotic keratitis. Journal of Clinical Microbiology 43(2): 662-668.

Lamit, L.J., Lau, M.K., Sthultz, C.M., Wooley, S.C., Whitham, T.G., Gehring, C.A. 2014. Tree genotype and genetically based growth traits structure twig endophyte communities. American Journal of Botany 101 (3): 467-478.

Li, J.Y., Sidhu, R.S., Ford, E.J., Long, D.M., Hess, W.M., Strobel, G.A. 1998. The induction of taxol production in the endophytic fungus - Periconia sp from Torreya grandifolia. Journal of Industrial Microbiology and Biotechnology 20(5): 259-264. Li, Z-J., Chen, S., Yang, X-H., Wang, R., Min, H-J., 
Asep Hidayat - Maman Turjaman • Sarah Asih Faulina • Fadel Ridwan •

Aryanto $\cdot$ Najmulah $\cdot$ Tun Tedja Irawadi $\cdot$ Apri Heri Iswanto

Wu, L., Si, C-L., Bae, Y-S. 2018. Secondary metabolites with anti-complementary activity from the stem barks of Juglans mandshuricaMaxim. Journal of the Korean Wood Science and Technology 46(2): 118-124.

Ascêncio, P.G.M., Ascêncio, S.D., Aguiar, A.A., Fiorini, A., Pimenta, R.S. 2014. Chemical assessment and antimicrobial and antioxidant activities of endophytic fungi extracts isolated from Costus spiralis (Jacq.) Roscoe (Costaceae). Evidence-based Complementary and Alternative Medicine 14(3): 1-10.

Mondol, M.A.M., Farthouse, J., Islam, M.T., Ffler, A.S., Laatsch, H. 2017. Metabolites from the endophytic fungus Curvularia sp. M12 act as motility inhibitors against Phytophthora capsici Zoospores. Journal of Natural Products 80(2): 347-355.

Naef, R. 2011. The volatile and semi-volatile constituents of agarwood, the infected heartwood of Aquilaria species: A review. Flavour and Fragrance Journal 26(2): 73-87.

Nimnoi, P., Pongsilp, N., Lumyong, S. 2010. Endophytic actinomycetes isolated from Aquilaria crassna Pierre ex Lec and screening of plant growth promoters production. World Journal of Microbiology and Biotechnology 26(2): 193-203.

Nimnoi, P., Pongsilp, N., Lumyong, S. 2011. Actinobacterial community and diversity in rhizosphere soils of Aquilaria crassna Pierre ex Lec assessed by RT-PCR and PCR-DGGE. Biochemical Systematic and Ecology 39(4-6): 509-519.

Oldfield, S., Lusty, C., MacKinven, A. 1998. The world list of threatened trees. World Conservation Press, Cambridge, UK.

Premalatha, K., Kalra, A. 2013. Molecular phylogenetic identification of endophytic fungi isolated from resinous and healthy wood of Aquilaria malaccensis, a red listed and highly exploited medicinal tree. Fungal Ecology 6(3): 205-211.
Qi, J., Lu, J.J., Liu, J.H., Yu, B.Y. 2009. Flavonoid and a rare benzophenone glycoside from the leaves of Aquilaria sinensis. Chemical \& Pharmaceutical Bulletin (Tokyo) 57(2): 134-137.

Sadeghi, Z., Valizadeh, J., Azyzian, S.O., Akaberi, M. 2015. Antioxidant activity and total phenolic content of Boerhavia elegans (choisy) grown in Baluchestan, Iran. Avicenna Journal of Phytomedicine 5(1): 1-9.

Saikia, P., Khan, M.L. 2013. Population structure and regeneration status of Aquilaria malaccensis Lam. in homegardens of Upper Assam, northeast India. Tropical Ecology 54(1): 1-13.

Santoso, E. (2013) Agarwood formation by fungal bioinduction. In: Susmianto A, Turjaman M, Setio $P$ (eds) Track record: agarwood inoculation technology by FORDA. FORDA Press, Bogor, Indonesia, p. 249.

Shoeb, M., Begum, S., Nahar, N. 2010. Study of an endophytic fungus from Aquilaria malaccensis Lamk. Bangladesh Journal of Pharmacology 5(1): 21-24.

Sitepu, I.R., Santoso, E., Siran, S.A., Turjaman, M. 2011. Fragrant wood gaharu: when the wild can no longer provide. ITTO and FORDA, Bogor, Indonesia.

Soehartono, T., Newton, A.C. 2000. Conservation and sustainable use of tropical trees in the genus Aquilaria I. Status and distribution in Indonesia. Biological Conservation 96(1): 83-94.

Staniek, A., Woerdenbag, H.J., Kayser, O. 2008. Endophytes: Exploiting biodiversity for the improvement of natural product-based drug discovery. Journal of Plant Interaction 3(2): 75-93.

Stierle, A., Strobel, G., Stierle, D. 1993. Taxol and taxane production by Taxomyces andreanae, an endophytic fungus of Pacific yew. Science 260 (5105): 214-216.

Strobel, G., Hess, W., Ford, E., Sidhu, R.S., Yang, X. 
1996. Taxol from fungal endophytes and the issue of biodiversity. Journal of Industrial Microbiology 17(5-6): 417-423.

Takemoto, H., Ito, M., Shiraki, T., Yagura, T., Honda, G. 2008. Sedative effects of vapor inhalation of agarwood oil and spikenard extract and identification of their active components. Journal of Natural Medicines 62(1): 41-46.

Tan, R.X., Zou, W.X. 2001. Endophytes: a rich source od functional metabolites. Natural Product Reports 18(4): 448-459.

Tanapichatsakul, C., Monggoot, S., Gentekaki, E., Pripdeevech, P. 2018. Antibacterial and antioxidant metabolites of Diaporthe spp. isolated from flowers of Melodorum fruticosum. Current Microbiology 75(4): 476-483.

Turjaman, M., Hidayat, A. 2017. Agarwood-planted tree inventory in Indonesia. In: IOP Conference Series: Earth and Environmental Science 54: 012062.

Turjaman, M., Hidayat, A., Santoso, E. 2016. Development of agarwood induction tecnology using endophytic fungi. In: Mohamed R (ed) Agarwood: Science behind the fragrance. Sipnger, Singapore, pp. 57-71.

Tapwal, A., Pradhan, S., Chandra, S., Rashmi. 2016. Short communication: Antimycotic activity and phytochemical screening of fungal endophytes associated with Santalum album. Nusantara Bioscience 8(1): 14-17.

Wang, Q.H., Peng, K., Tan, L.H., Dai, H.F. 2010. Aquilarin A, a new benzenoid derivative from the fresh stem of Aquilaria sinensis. Molecules 15(6): 4011-4016.

Wetwitayaklung, P., Thavanapong, N., Charoenteeraboon, J. 2009. Chemical constituents and antimicrobial activity of essential oil and extracts of heartwood of Aquilaria crassna obtained from water distillation and supercritical fluid carbon dioxide extraction. Silpakorn University Science and Technology Journal 3(1): 25-33.

Wheeler, K.A., Hocking, A.D. 1993. Interactions among xerophilic fungi associated with dried salted fish. Journal of Applied Bacteriology 74(2): 164-169.

Yoshimi, N., Matsunaga, K., Katayama, M., Yamada, Y., Kuno, T., Qiao, Z, Hara, A., Yamahara, J., Mori, H. 2001. The inhibitory effects of mangiferin, a naturally occurring glucosylxanthone, in bowel carcinogenesis of male F344 rats. Cancer Letters 163(2): 163-170.

Zhang, Z., Wei, J., Han, X., Liang, L., Yang, Y., Meng, H., Xu, Y., Gao, Z. 2014. The sesquiterpene biosynthesis and vessel-occlusion formation in stems of Aquilaria sinensis(lour.) gilg trees induced by wounding treatments without variation of microbial communities. International Journal of Molecular Science 15(2): 23589-23603.

Zhou, W.N., White, J.F., Soares, M.A., Torres, M.S., Zhou, Z.P., Li, H.Y. 2015. Diversity of fungi associated with plants growing in geothermal ecosystems and evaluation of their capacities to enhance thermotolerance of host plants. Journal ofPlant Interactions 10(1): 305-314. 